\section{Cold Tolerance of Container-grown Green Ash Trees Is Influenced by Nitrogen Fertilizer Type and Rate}

\author{
Carolyn F. Scagel ${ }^{1,5}$, Richard P. Regan ${ }^{2}$, Rita Hummel ${ }^{3}$, \\ and Guihong $\mathrm{Bi}^{4}$
}

\begin{abstract}
Additional INDEX wORDs. Fraxinus pennsylvanica, allocation, bud failure
Summary. A study was conducted to determine whether nitrogen (N) application rate and fertilizer form are related to cold tolerance of buds and stems using container-grown 'Summit' green ash (Fraxinus pennsylvanica) trees. Trees were grown with different rates of $\mathrm{N}$ from either urea formaldehyde (UF) or a controlledrelease fertilizer (CRF) containing ammonium nitrate during the 2006 growing season; and growth, $\mathrm{N}$ and carbon $(\mathrm{C})$ composition, and cold tolerance were evaluated in Oct. 2006, Dec. 2006, and Feb. 2007 by assessing the lowest survival temperature (LST) of stem and bud tissues on current season (2006) stems. Both fertilizer type and rate influenced the bud and stem LSTs. The influence of fertilizer rate was most evident on midwinter (December) stem LSTs and the influence of fertilizer type was observed in bud and stem LSTs during the deacclimation period in February. Higher LSTs were associated with higher $\mathrm{N}$ concentrations and lower $\mathrm{C} / \mathrm{N}$ ratios; however, stems and buds of trees fertilized with UF were more coldtolerant (had lower LSTs) than stems and buds on trees fertilized with CRF. Fertilizer type resulted in several differences in $\mathrm{N}$ and $\mathrm{C}$ translocation and metabolism during the fall and winter. Our results indicate trees with a similar $\mathrm{N}$ status are able to withstand different levels of cold depending on the rate of $\mathrm{N}$ and the type or form of fertilizer used during production. This may have to do with differences in how trees metabolize the different fertilizer forms, where and when the $\mathrm{N}$ is stored, and how it is remobilized in the spring, especially in relation to $\mathrm{C}$ metabolism.
\end{abstract}

$\mathrm{W}$ inter injury to containerand field-grown trees and shrubs is often observed in nursery grown plants in Oregon and other states in the Pacific northwestern United States (PNW). Severe freeze events occur only periodically in the PNW; however, winter injury can occur as a result of moderate lowtemperature events $\left(-10\right.$ to $\left.-5{ }^{\circ} \mathrm{C}\right)$. The phrase "winter injury" is commonly used to describe why shoot dieback and bud failure occur in the spring when no pathogen is present. Bud failure in the spring can be correlated with low nitrogen $(\mathrm{N})$ reserves in trees and several studies have

\footnotetext{
${ }^{1}$ U.S. Department of Agriculture, Agricultural Research Service, Horticultural Crops Research Unit, 3420 NW Orchard Avenue, Corvallis, OR 97330

${ }^{2}$ Department of Horticulture, North Willamette Research and Extension Center, Oregon State University, Aurora, OR 97002-9543

${ }^{3}$ Puyallup Research and Extension Center, Washington State University, 7612 Pioneer Way E., Puyallup, WA 98371-4998

${ }^{4}$ Truck Crops Branch Experiment Station, Mississippi State University, 2024 Experiment Station Road, Crystal Springs, MS 39059

${ }^{5}$ Corresponding author. E-mail: Carolyn.Scagel@ars.
} usda.gov. evaluated different fertilizer management practices for improving $\mathrm{N}$ status of trees in the fall (Bi et al., 2005). Also, it is well known that application of $\mathrm{N}$ fertilizers late in the growing season can decrease cold-hardiness and increase the potential for cold injury to buds and stems (Fløistad and Kohmann, 2004; Pellett et al., 1981; Thomas and Ahlers, 1999). In a previous study we investigated whether bud necrosis in green ash was associated with tree $\mathrm{N}$ status and observed that it was more influenced by fertilizer type than by $\mathrm{N}$ application rate (Scagel et al., 2010). The specific relationships among cold tolerance, plant $\mathrm{N}$ status, fertilizer formulations, and fertilizer application timing have not been well investigated for woody perennial nursery crops. Fertilizer type also differentially influenced how trees stored and remobilized $\mathrm{N}$ and carbon $(\mathrm{C})$ reserves from different tissues (Scagel et al., 2010). This led us to hypothesize that the influence of fertilizer type on bud failure is a result of differences in cold-hardiness between trees grown with the different fertilizer types.

Nitrogen fertilizer practices in the nursery can contribute to plant cold tolerance; however, there are conflicting reports regarding the effect of fertilizer application rate on cold tolerance of herbaceous and woody perennial plants. There are reports of negative relationships between $\mathrm{N}$ status and cold-hardiness (Calmé and Margolis, 1993; Hellergren, 1981; Smiley and Shirazi, 2003), positive relationships (Bigras et al., 1996; Rikala and Repo, 1997; Smiley and Shirazi, 2003), and no relationship (Birchler et al., 2001; Fløistad, 2002; Munshaw et al., 2006). Several researchers have addressed how timing of $\mathrm{N}$ application can influence cold-hardiness development, but there is little mention of how application method (Guak and Fuchigami, 2002 ) or fertilizer type influences cold-hardiness or relationships between plant $\mathrm{N}$ status and deacclimation. Increasing rate of $\mathrm{N}$ application can decrease cold tolerance in the fall or accelerate cold deacclimation in the spring (Calmé and Margolis, 1993; Fløistad and Kohmann, 2004; Hellergren, 1981; Pellett and Carter, 1981). Initial shoot growth in the spring is dependent on nutrient reserves accumulated during the previous year (Bi et al., 2005); however, if too much fertilizer is applied late in summer, then growth may be prolonged and cold damage incurred (Bigras et al., 1996). The type of

\begin{tabular}{llll}
\hline $\begin{array}{l}\text { Units } \\
\text { To convert U.S. to SI, } \\
\text { multiply by }\end{array}$ & U.S. unit & SI unit & $\begin{array}{l}\text { To convert SI to U.S., } \\
\text { multiply by }\end{array}$ \\
\hline 0.3048 & $\mathrm{ft}$ & $\mathrm{m}$ & 3.2808 \\
3.7854 & $\mathrm{gal}$ & $\mathrm{L}$ & 0.2642 \\
2.54 & inch(es) & $\mathrm{cm}$ & 0.3937 \\
1.6093 & $\mathrm{mph}$ & $\mathrm{km} \cdot \mathrm{h}^{-1}$ & 0.6214 \\
28.3495 & $\mathrm{oz}$ & $\mathrm{g}$ & 0.0353 \\
28,350 & $\mathrm{oz}$ & $\mathrm{mg}$ & $3.5274 \times 10^{-5}$ \\
0.001 & $\mathrm{ppm}$ & $\mathrm{mg} \cdot \mathrm{g}^{-1}$ & 1000 \\
$\left({ }^{\circ} \mathrm{F}-32\right) \div 1.8$ & ${ }^{\circ} \mathrm{F}$ & ${ }^{\circ} \mathrm{C}$ & $\left(1.8 \times{ }^{\circ} \mathrm{C}\right)+32$ \\
& & &
\end{tabular}


fertilizer used to grow green ash trees can alter how trees store reserves in the fall and remobilize them in the spring (Scagel et al., 2010); therefore, it is possible fertilizer type could influence cold-hardiness development in the fall and winter and deacclimation in the spring.

There is little information available on the influence of fertilizer type on plant cold tolerance and timing of spring growth. Fertilizer type can influence fall $\mathrm{N}$ allocation and the timing of early spring $\mathrm{C}$ and $\mathrm{N}$ metabolism in stems of green ash (Scagel et al., 2010); therefore, differences in cold tolerance between trees fertilized with different rates or types of fertilizer may be related to differences in fall $\mathrm{N}$ allocation and timing of spring metabolic activity. Separation of the changes that occur during dormancy development with those that occur during cold acclimation is difficult for woody perennial plants (Kalberer et al., 2007). Additionally, active development (lack of dormancy) promotes deacclimation and reduces reacclimation capacity (Colombo et al., 2003). There is a dynamic change of compounds that are associated with acclimation and cold tolerance and both $\mathrm{C}$-rich and $\mathrm{N}$-rich defenses are important to plant survival in the winter (Livingston et al., 2006; Watanabe et al., 2008). Although our knowledge of the processes that regulate plant cold acclimation, deacclimation, and reacclimation capacity has improved substantially during the last few decades, our knowledge of how cultural practices can influence these processes has lagged. Examining how cultural practices such as $\mathrm{N}$ rate and fertilizer type influence the dynamics of $\mathrm{N}$ and $\mathrm{C}$ in the plant during cold acclimation and deacclimation may aid in the development of indicator criteria for grower use as well as improving our basic understanding of how nutrient management practices can influence plant cold tolerance.

To our knowledge, the only information available on cold tolerance of green ash is from natural ecosystems and landscape plantings (Aniśko et al., 1994; Cappiello and Littlefield, 1994; Pukacki and Przybył, 2005), and the applicability of this information to nursery production conditions is unknown. Nursery production of green ash has decreased in the midwest as a result of recent increased activity of the invasive Asian beetle known as the emerald ash borer (Agrilus planipennis); however, shade tree nurseries in the PNW are still growing green ash trees for the market on the west side of the Rocky Mountains. Our previous research suggested that $\mathrm{N}$ application rate and $\mathrm{N}$ form play a role in bud failure of green ash (Scagel et al., 2010). Using this tree species as a model for fast-growing shade trees, the objective of this study was to determine whether $\mathrm{N}$ application rate and fertilizer type differentially influence cold tolerance of green ash.

\section{Materials and methods}

One-year-old bareroot fieldbudded green ash (J. Frank Schmidt \& Sons, Boring, OR) were grown in 7-gal containers using a douglas fir bark-based substrate at the Oregon State University, North Willamette Research and Extension Center at Aurora (lat. $45^{\circ} 22^{\prime} \mathrm{N}$, long. $122^{\circ} 80^{\prime}$ $\mathrm{W})$. The trees were grown on gravel under a retractable roof structure and irrigated with microsprinklers located at the surface of the container substrate of each tree. Trees were irrigated daily, as needed, to an estimated 0.2 leaching fraction. Shoots in the tree canopy were not pruned. The roof remained open for the duration of the study and was only closed when high wind warnings for the region predicted gusts over $50 \mathrm{mph}$. The trees were subject to outside air temperatures and freeze events with the lowest temperature events occurring between 12 Jan. and 15 Jan. 2007 with lows ranging from -5 to $-6^{\circ} \mathrm{C}$ as recorded by the AgriMet automated weather station located $100 \mathrm{~m}$ from the study site. Between 1 Oct. 2006 and 24 Oct. 2006, minimum air temperature was never below $2{ }^{\circ} \mathrm{C}$ (24 Oct. 2006). Between 24 Oct. 2006 and 11 Dec. 2006, minimum air temperature was never below $-2{ }^{\circ} \mathrm{C}$ (11 Nov. 2006), 8 d had minimum air temperature below $0{ }^{\circ} \mathrm{C}, 18 \mathrm{~d}$ had minimum air temperature below $2{ }^{\circ} \mathrm{C}$, and maximum air temperature was always above $2{ }^{\circ} \mathrm{C}$. Between 11 Dec. 2006 and 5 Feb. 2007, minimum air temperature was never below $-6{ }^{\circ} \mathrm{C}$ (13 Jan. 2007), $6 \mathrm{~d}$ had minimum air temperatures below $-4{ }^{\circ} \mathrm{C}, 31 \mathrm{~d}$ had minimum air temperature below $0{ }^{\circ} \mathrm{C}$, and $2 \mathrm{~d}$ maximum air temperature was not above $0{ }^{\circ} \mathrm{C}$.

The container substrate was a commercial mix (Pro-Gro Mixes and Materials, Sherwood, OR) consisting of douglas fir bark (75\%), pumice $(15 \%)$, and peatmoss $(10 \%)$ amended with micronutrients and dolomite limestone to obtain a $\mathrm{pH}$ of 6.7. A starter charge of $11.6 \mathrm{~g} \mathrm{~N}$ (35\% urea formaldehyde $+65 \%$ potassium nitrate) was incorporated to compensate for the $\mathrm{N}$ drawdown associated with bark substrates (Buamscha et al., 2008). Trees either received no $\mathrm{N}$ fertilizer $(0 \mathrm{~N})$ or were fertilized with $\mathrm{N}$ at one of two rates ( 16 or $32 \mathrm{~g}$ total $\mathrm{N})$ on 5 May, 21 June, and 11 Aug. 2006 by topdressing urea formaldehyde (16-UF, 32-UF) on the surface of the growing substrate or on 5 May 2006 by topdressing a controlledrelease fertilizer [16-CRF, 32-CRF (Osmocote Classic (C) 18-6-12; Scotts Horticulture, Marysville, $\mathrm{OH}$ )] at planting (N Treatment). Trees fertilized with UF also received equivalent amounts of phosphorus (P) and potassium $(\mathrm{K})$ as compared with the $\mathrm{P}$ and $\mathrm{K}$ in the 16-CRF and 32-CRF treatments (elemental $\mathrm{P}$ from triple superphosphate, $16-\mathrm{UF}=2.4 \mathrm{~g} \mathrm{P}$, $32-\mathrm{UF}=4.8 \mathrm{~g} \mathrm{P}$; and elemental $\mathrm{K}$ from potassium sulfate, $16-\mathrm{UF}=9.0 \mathrm{~g}$ $\mathrm{K}, 32-\mathrm{UF}=18.0 \mathrm{~g} \mathrm{~K}$ ). The $\mathrm{P}$ and $\mathrm{K}$ were applied as split topdressing applications on the same dates as the UF $\mathrm{N}$ treatments. The rate of total $\mathrm{N}$ application and formulation for the CRF treatment was chosen based on results from previous experiments with this cultivar.

On 24 Oct. 2006, 11 Dec. 2006, and 5 Feb. 2007, five trees in each $\mathrm{N}$ treatment were harvested. Singlenode, 6- to 8-cm subsamples of 2006 stems were taken for determination of lowest survival temperature (LST) at 12 temperatures $(-12,-15,-18,-20$, $-22,-24,-26,-28,-30,-32,-36$, and $-40{ }^{\circ} \mathrm{C}$ ) in a polyethylene glycol bath using established methods (Hummel et al., 1982; Teets et al., 1989). The LST, the lowest temperature at which little or no injury was observed, was determined by dissection and visual evaluation of tissue injury with the aid of a dissecting microscope (Sterigios and Howell, 1973 ) on five stems and 10 buds from each $\mathrm{N}$ treatment at each freeze test temperature. The remaining portions of the 2006 stems and subsamples of 
2005 stems, coarse roots, and fine roots were oven-dried and weighed and samples were ground and analyzed for $\mathrm{N}$ and $\mathrm{C}$ by automated combustion with an elemental analyzer using established methods (Scagel et al., 2007). Total $\mathrm{N}$ and $\mathrm{C}$ contents of each structure were calculated based on the weight and $\mathrm{N}$ and $\mathrm{C}$ concentrations in each structure. Buds were visually assessed once per week from 6 Mar. through 9 Apr. 2007 and bud break was determined when at least $50 \%$ of the buds per tree were swollen (separation of bud scales).

The experiment was a randomized block design with five replications for each of the five $\mathrm{N}$ treatments at each of the three harvest dates. Growth and composition data were analyzed using analysis of variance in a complete factorial design with $\mathrm{N}$ treatment and harvest date as main effects. Specific a priori contrasts were used to characterize the influence of $\mathrm{N}$ rate, fertilizer type, and date on response variables. The LST data were analyzed using $\mathrm{K}-\mathrm{W}_{0.05}$ to determine the influence of fertilizer treatment and date on LST of bud and stem tissue from 2006 stems. Correlations between composition data and LST data were assessed using Spearman rank correlation (R) at $P<$ 0.05 . All statistical analyses were performed with Statistica ${ }^{\circledR}$ (Version 8; StatSoft, Tulsa, OK).

\section{Results}

LOWEST SURVIVAL TEMPERATURES OF BUD AND STEM TISSUE. Cold tolerance of buds and stems of green ash trees increased (lower LSTs) between Oct. 2006 and Dec. 2006 for all treatments and, in general, cold tolerance decreased (higher LSTs) between Dec. 2006 and Feb. 2007 (Fig. 1A-B). The influence of fertilizer type (CRF versus UF) and rate of $\mathrm{N}$ application ( $\mathrm{N}$ rate) on cold tolerance varied between dates and between bud and stem tissue. Stems on trees in the $0 \mathrm{~N}$ treatment during $2006(0 \mathrm{~N}$ trees) were more cold-tolerant than stems on trees fertilized with CRF (CRF trees) or UF (UF trees). Buds on $0 \mathrm{~N}$ trees were more cold-tolerant than buds on CRF trees at all harvest dates and buds on $0 \mathrm{~N}$ trees were more cold-tolerant than buds on UF trees in Oct. 2006. Nitrogen rate in 2006 had no influence on bud cold tolerance. Stem cold tolerance of CRF trees was not influenced by $\mathrm{N}$ rate. Cold tolerance of stems on UF trees was not influenced by $\mathrm{N}$ rate in October and Dec. 2006; however, stems on trees grown with $32 \mathrm{~g} \mathrm{~N}$ from UF (32-UF trees) were less cold-tolerant than stems on trees grown with $16 \mathrm{~g} \mathrm{~N}$ from UF (16UF trees) in Feb. 2007.

The relationship between cold tolerance of stems and buds was influenced by fertilizer type and date (Fig. IC). In Oct. and Dec. 2006, stems were generally more cold-tolerant than buds, and in Feb. 2007, stems were similar or slightly less cold-tolerant than buds. In general, CRF trees with more cold-tolerant buds had more cold-tolerant stems at all dates and UF trees with more cold-tolerant buds had more cold-tolerant stems only in Oct. 2006.

Growth. Increased $\mathrm{N}$ rate increased the biomass and $\mathrm{N}$ content of 2006 stems, biomass and $\mathrm{N}$ content of 2006 stems on CRF trees was greater than UF trees, $\mathrm{N}$ rate had a greater influence on biomass, and $\mathrm{N}$ content of 2006 stems from CRF trees than UF trees [Fig. 1D (N content data not shown)]. Biomass of 2006 stems remained stable between Oct. 2006 and Feb. 2007; therefore, differences in $\mathrm{N}$ and $\mathrm{C}$ concentration in 2006 stems between Oct. 2006 and Feb. 2007 were interpreted as a net result of changes in $\mathrm{N}$ and $\mathrm{C}$ export, import, or metabolism and differences in $\mathrm{C} / \mathrm{N}$ ratios were used to assess the magnitude of loss and accumulation when concurrent changes in $\mathrm{C}$ and $\mathrm{N}$ concentrations occurred. Biomass of old stems on container-grown deciduous and evergreen plants have been reported to remain stable during the winter (October to February) (Scagel et al., 2008a, 2008b); therefore, we assumed there was no net change in biomass of 2005 stems between Oct. 2006 and Feb. 2007, and differences in $\mathrm{N}$ concentrations and $\mathrm{C} / \mathrm{N}$ ratios between these dates in 2005 stems were also interpreted as changes in $\mathrm{C}$ and $\mathrm{N}$ translocation and metabolism.

Total biomass of fine and coarse roots between Oct. 2006 and Feb. 2007 was not determined. Biomass of roots on container-grown deciduous and evergreen plants can remain stable during the fall and winter, increase, or decrease (Scagel et al., 2008a, 2008b); therefore, we cannot assume there was no change in biomass of roots between Oct. 2006 and Feb. 2007. Differences in N concentrations and $\mathrm{C} / \mathrm{N}$ between these dates were interpreted as changes resulting from biomass, translocation, and metabolism.

Fertilizer type and application rate influenced the time of bud break in Spring 2007. The CRF trees broke bud (greater than $50 \%$ of buds swollen and beginning to elongate) on 6 Mar. 2007; the 32-UF trees broke bud on 13 Mar. 2007, the 16-UF trees broke bud on 20 Mar. 2007, and the $0 \mathrm{~N}$ trees broke bud on 26 Mar. 2007.

COMPOSITION, TRANSLOCATION, and METABolism. Fertilizer type altered the timing of $\mathrm{N}$ and $\mathrm{C}$ translocation and metabolism in stems and roots during the fall and winter [Figs. $2 \mathrm{~A}-\mathrm{B}, 3 \mathrm{~A}-\mathrm{B}, 4 \mathrm{~A}-\mathrm{B}$, and $5 \mathrm{~A}-\mathrm{B}(\mathrm{C}$ concentration data not shown)]. Between Oct. and Dec. 2006, 0N trees lost $\mathrm{N}$ and accumulated $\mathrm{C}$ in new stems; CRF trees lost $\mathrm{N}$ from new stems and accumulated $\mathrm{N}$ in roots and old stems and lost $\mathrm{C}$ from old stems and coarse roots and accumulated $\mathrm{C}$ in new stems and $\mathrm{C}$ fine roots; and UF trees accumulated $\mathrm{N}$ in stems and coarse roots and accumulated $\mathrm{C}$ in new stems and coarse roots. Between Dec. 2006 and Feb. 2007, 0N trees lost $\mathrm{N}$ from stems and roots and accumulated $\mathrm{C}$ in stems; CRF trees lost $\mathrm{N}$ from stems and coarse roots and accumulated $\mathrm{N}$ in fine roots and accumulated $\mathrm{C}$ in stems and coarse roots; and UF trees lost $\mathrm{N}$ in stems and coarse roots and accumulated $\mathrm{N}$ in fine roots and accumulated $\mathrm{C}$ in old stems.

Differences between CRF and UF trees occurred with $\mathrm{N}$ changes in new stems and fine roots and $\mathrm{C}$ changes in old stems and roots between Oct. and Dec. 2006 and with C changes in new stems and coarse roots between Dec. 2006 and Feb. 2007. Differences between $0 \mathrm{~N}$ and CRF trees occurred with $\mathrm{N}$ and $\mathrm{C}$ changes in roots and old stems between Oct. and Dec. 2006. Differences between $0 \mathrm{~N}$ and UF trees occurred with $\mathrm{N}$ changes in stems and coarse roots and $C$ changes in new stems and coarse roots between Oct. and Dec. 2006 and $\mathrm{N}$ changes in fine roots and $\mathrm{C}$ changes in new stems between Dec. 2006 and Feb. 2007. 

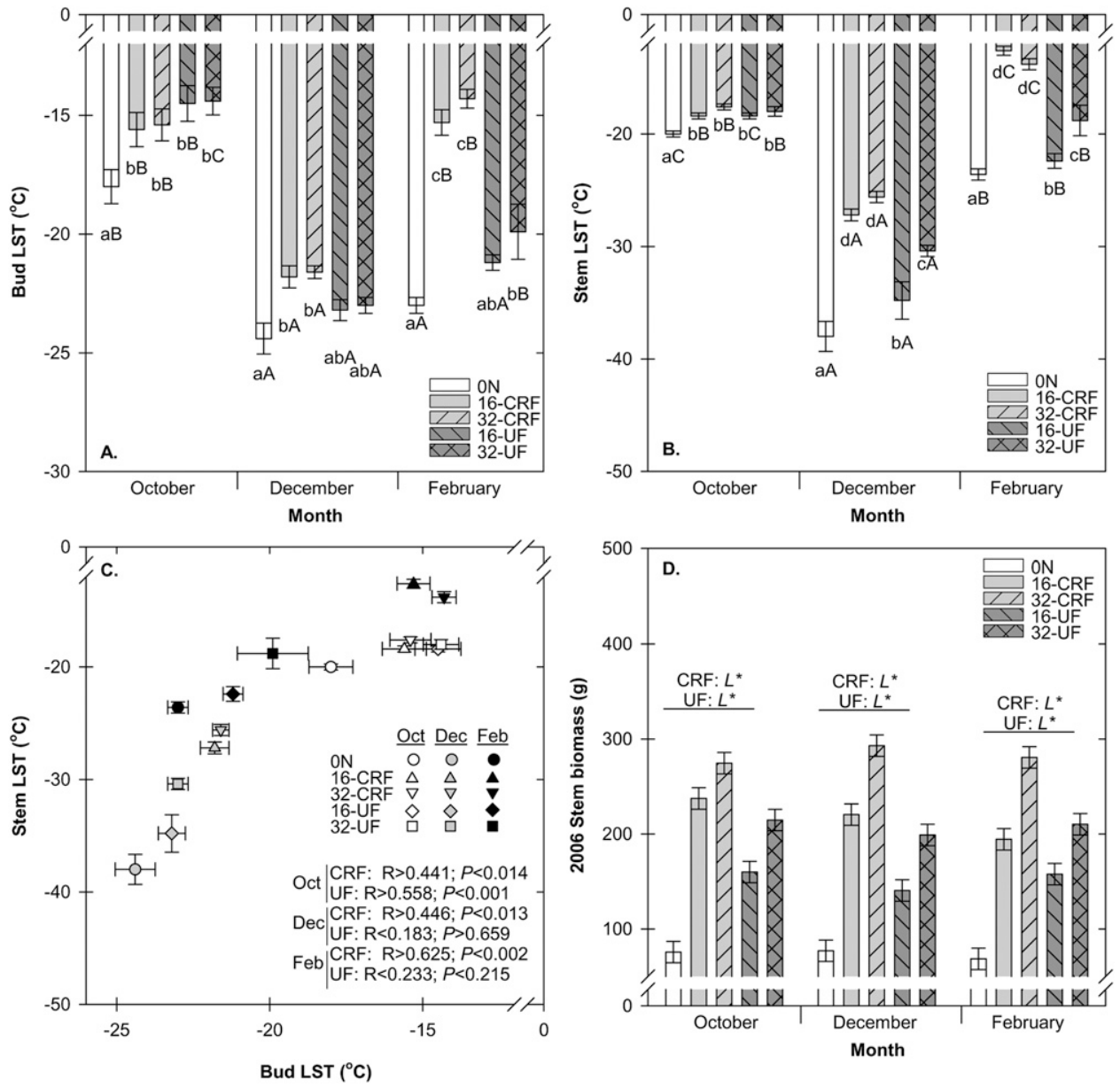

Fig. 1. Lowest surviving temperature (LST) of bud and stem tissue from current-year (2006) stems and biomass of 2006 stems of green ash trees grown with different rates of nitrogen $(\mathrm{N})$ from two types of fertilizers in 2006. Measurements were taken on 24 Oct. 2006 (Oct), 11 Dec. 2006 (Dec), and 5 Feb. 2007 (Feb). 0N = trees received no N. CRF = trees fertilized with $16 \mathrm{~g} \mathrm{~N}$ (16-CRF) or $32 \mathrm{~g} \mathrm{~N}$ (32-CRF) from a controlled-release fertilizer. UF = trees fertilized with $16 \mathrm{~g} \mathrm{~N}$ (16-UF) or $32 \mathrm{~g}$ N (32-UF) from urea formaldehyde. Values are means and error bars are sE (A: $\mathbf{n}=10 ; \mathrm{B}, \mathrm{C}, \mathrm{D}: \mathbf{n}=\mathbf{5})$. (A-B) Influence of $\mathrm{N}$ treatment ( $\mathrm{N}$ treatment) on LSTs. Columns within a date denoted by different lower case letters indicate significant differences between $\mathrm{N}$ treatment; columns within an $\mathrm{N}$ treatment denoted by different upper case letters indicate significant differences between dates (Kruskal-Wallis at $P>\mathbf{0 . 0 5}$ ). (C) Graphical representation of relationships between bud LSTs and stem LSTs and $P$ values for Spearman rank correlations $(R)$ within date and fertilizer type. (D) Influence of nitrogen treatment $(N$ treatment) on biomass of 2006 stems. Significant (contrast $P<0.05$ ) linear $(L)$ responses to $\mathrm{N}$ rate within a fertilizer type and date denoted above columns. Significant $(P<0.05)$ differences between fertilizer types in response to $\mathrm{N}$ rate within a date denoted by asterisks ( $\left.{ }^{*}\right)$ adjacent to contrast letters above columns. Biomass of 2006 stems within each $\mathrm{N}$ treatment did not significantly (contrast $P>0.05$ ) change between dates; $1 \mathrm{~g}=0.0353 \mathrm{oz} ;\left(1.8 \times{ }^{\circ} \mathrm{C}\right)+32={ }^{\circ} \mathrm{F}$.

The availability of $\mathrm{N}$ during the growing season and fertilizer type altered $\mathrm{C} / \mathrm{N}$ ratios and how trees balanced $\mathrm{N}$ and $\mathrm{C}$ in stems and roots (Figs. 2A-B, 3A-B, 4A-B, and 5A$B$ ). Increased $N$ rate decreased $C / N$ ratios in new stems of CRF trees as a result of higher $\mathrm{N}$ import than $\mathrm{C}$ import (Oct. 2006) and N import and C export (Dec. 2006 and Feb. 2007). In contrast, increased $\mathrm{N}$ rate decreased $\mathrm{C} / \mathrm{N}$ ratios in new stems of $\mathrm{UF}$ trees as a result of $\mathrm{N}$ import and no net change in C (Dec. 2006) and $\mathrm{N}$ import and $\mathrm{C}$ export (Feb. 2007). Increased $\mathrm{N}$ rate decreased $\mathrm{C} / \mathrm{N}$ ratios in old stems of CRF trees as a result of $\mathrm{N}$ import and $\mathrm{C}$ export (Oct. 2006, Dec. 2006, and Feb. 2007). In contrast, increased $\mathrm{N}$ rate decreased $\mathrm{C} / \mathrm{N}$ ratios in old stems of $\mathrm{UF}$ trees as a result of $\mathrm{N}$ import and no net change in C (Oct. 2006 and Dec. 2006) and $\mathrm{N}$ import and $\mathrm{C}$ export (Feb. 2007). Increased $\mathrm{N}$ rate decreased $\mathrm{C} / \mathrm{N}$ ratios in fine roots trees as a result of $\mathrm{N}$ import and $\mathrm{C}$ export (Oct. 2006, Dec. 2006, and Feb. 2006). Increased $\mathrm{N}$ rate decreased $\mathrm{C} / \mathrm{N}$ ratios in coarse root trees as a result of $\mathrm{N}$ import (Oct. 2006, Feb. 2007) and N import and
C export (Dec. 2006). Increased $\mathrm{N}$ rate decreased $\mathrm{C} / \mathrm{N}$ ratios in coarse roots of UF trees as a result of $\mathrm{N}$ import (Oct. 2006), N import, and C export (Dec. 2007).

RELATIONSHIPS BETWEEN LOWEST SURVIVAL TEMPERATURES AND COMPOSITION. Relationships between $\mathrm{N}$ and $\mathrm{C}$ composition and LSTs occurred at several harvest dates and varied between tissues (Figs. 2C$\mathrm{F}, 3 \mathrm{C}-\mathrm{F}, 4 \mathrm{C}-\mathrm{F}$, and $5 \mathrm{C}-\mathrm{F})$. Greater cold tolerance in Oct. 2006 was related to lower $\mathrm{N}$ concentrations and higher C/N ratios in 2005 stems, coarse roots, and fine roots. Greater 

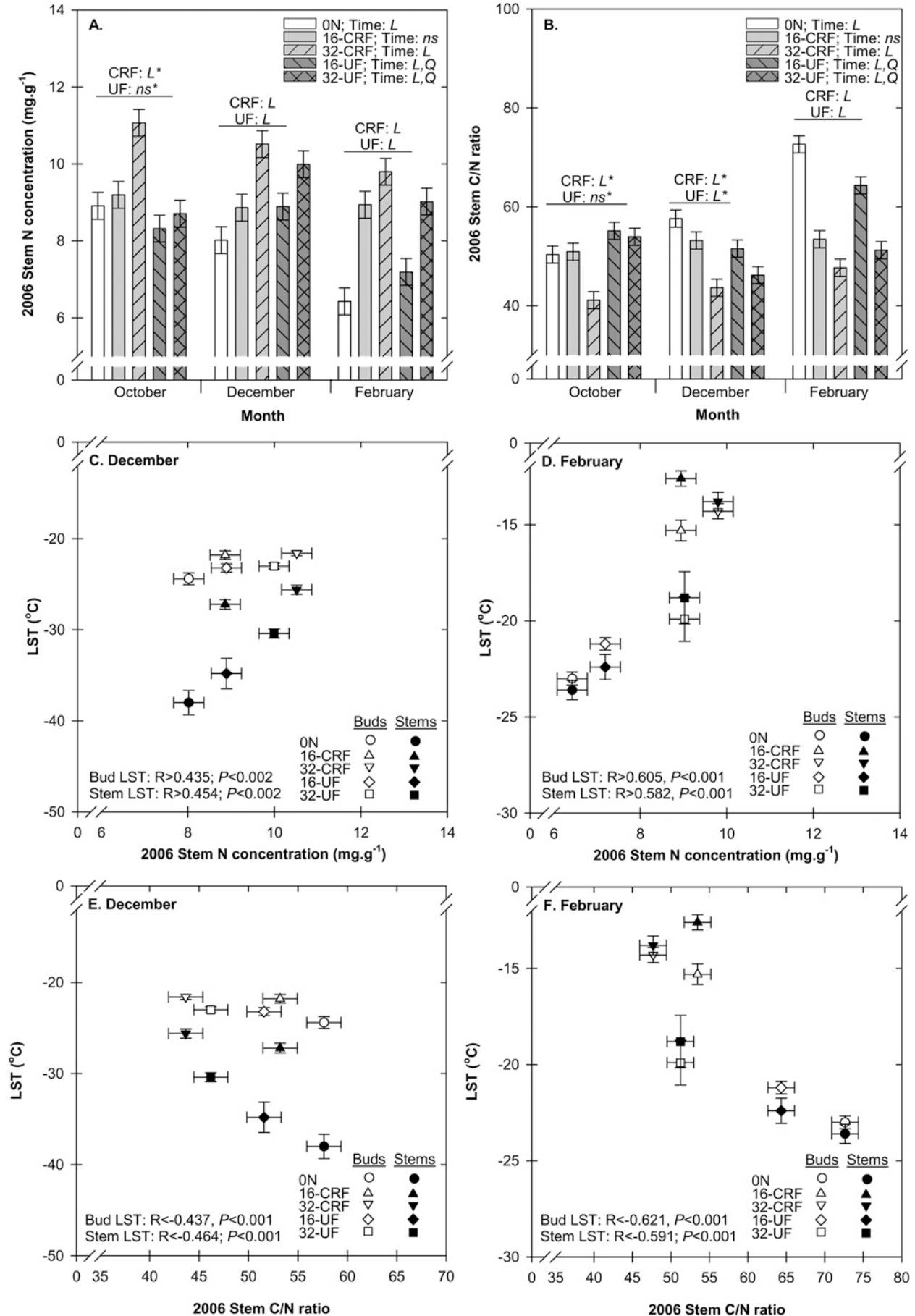

Fig. 2. Nitrogen $(\mathrm{N})$ concentration and carbon to $\mathrm{N}(\mathrm{C} / \mathrm{N})$ ratio in current-year $(2006)$ stems of green ash trees grown with different rates of $\mathrm{N}$ from two types of fertilizers in 2006. Measurements were taken on 24 Oct. 2006, 11 Dec. 2006, and 5 Feb. 2007. $0 \mathrm{~N}=$ trees received no $\mathrm{N}$. CRF $=$ trees fertilized with $16 \mathrm{~g} \mathrm{~N}$ (16-CRF) or $32 \mathrm{~g} \mathrm{~N}$ (32-CRF) from a controlled-release fertilizer. UF = trees fertilized with $16 \mathrm{~g} \mathrm{~N}$ (16-UF) or $32 \mathrm{~g} \mathrm{~N}$ (32-UF) from urea formaldehyde. Values are means and error bars are SE. (A-B) Influence of $\mathrm{N}$ treatment $(\mathrm{N}$ treatment) on $\mathrm{N}$ concentration and $\mathrm{C} / \mathrm{N}$ ratios. Significant (contrast $P<0.05$ ) linear $(L)$ responses to $\mathrm{N}$ rate within a fertilizer type and date denoted above columns. Significant $(P<0.05)$ differences between fertilizer types in response to $\mathrm{N}$ rate within a date denoted by asterisks $\left({ }^{*}\right)$ adjacent to contrast letters above columns. Nonsignificant (NS) and significant (contrast $P>0.05) L$ and quadratic $(Q)$ responses over time within an $N$ treatment denoted in captions. (C-F) Graphical representation of relationships between $\mathrm{N}$ concentrations and $\mathrm{C} / \mathrm{N}$ ratios and the lowest surviving temperature (LST) of buds and stems, including $P$ values for Spearman rank correlations $(R)$ within tissue type. There were no significant relationships between LSTs and $\mathrm{N}$ concentrations and $\mathrm{C} / \mathrm{N}$ ratios in Oct. 2006 (data not shown); $1 \mathrm{~g}=0.0353 \mathrm{oz} ; 1 \mathrm{mg} \cdot \mathrm{g}^{-1}=1000 \mathrm{ppm} ;\left(1.8 \times{ }^{\circ} \mathrm{C}\right)+32={ }^{\circ} \mathrm{F}$. 

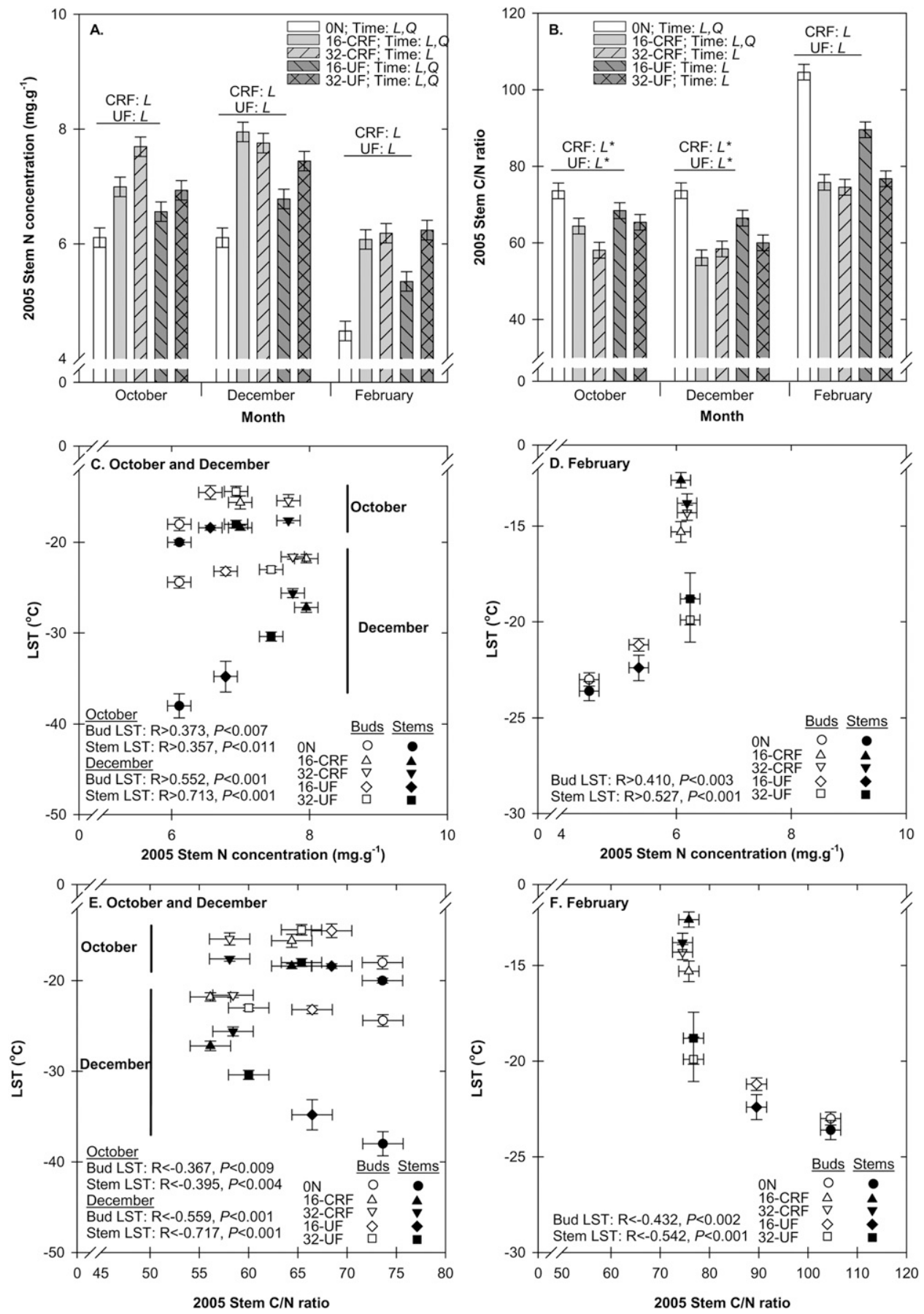

Fig. 3. Nitrogen (N) concentration and carbon to $\mathrm{N}(\mathrm{C} / \mathrm{N})$ ratio in old (2005) stems of green ash trees grown with different rates of $\mathrm{N}$ from two types of fertilizers in 2006. Measurements were taken on 24 Oct. 2006, 11 Dec. 2006, and 5 Feb. 2007. $0 \mathrm{~N}=$ trees received no $\mathrm{N}$. CRF $=$ trees fertilized with $16 \mathrm{~g} \mathrm{~N}(16-\mathrm{CRF})$ or $32 \mathrm{~g} \mathrm{~N}$ (32-CRF) from a controlled-release fertilizer. $\mathrm{UF}=$ trees fertilized with $16 \mathrm{~g} \mathrm{~N}(16-\mathrm{UF})$ or $32 \mathrm{~g} \mathrm{~N}(32-\mathrm{UF})$ from urea formaldehyde. Values are means and error bars are SE. (A-B) Influence of $\mathrm{N}$ treatment $(\mathrm{N}$ treatment) on $\mathrm{N}$ and $\mathrm{C} / \mathrm{N}$ ratios. Significant (contrast $P<0.05)$ linear $(L)$ responses to $\mathrm{N}$ rate within a fertilizer type and date denoted above columns. Significant $(P<0.05)$ differences between fertilizer types in response to $\mathrm{N}$ rate within a date denoted by asterisks $\left({ }^{*}\right)$ adjacent to contrast letters above columns. Nonsignificant (NS) and significant (contrast $P>0.05) L$ and quadratic $(Q)$ responses over time within an $\mathrm{N}$ treatment denoted in captions. (C-F) Graphical representation of relationships between $\mathrm{N}$ concentrations and $\mathrm{C} / \mathrm{N}$ ratios and the lowest surviving

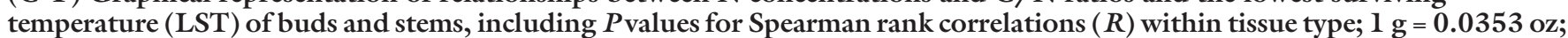
$1 \mathrm{mg} \cdot \mathrm{g}^{-1}=1000 \mathrm{ppm} ;\left(1.8 \times{ }^{\circ} \mathrm{C}\right)+32={ }^{\circ} \mathrm{F}$.

cold tolerance in Dec. 2006 and Feb. 2007 was related to lower $\mathrm{N}$ concentrations and higher $\mathrm{C} / \mathrm{N}$ ratios in stems and roots.
The cold tolerance of buds and stems increased between Oct. and Dec. 2006 (Fig. 1A-B) and was related to $\mathrm{N}$ export $(0 \mathrm{~N}$ and $\mathrm{CRF}$ trees), $\mathrm{N}$ accumulation (UF trees), and $\mathrm{C}$ accumulation $(\mathrm{ON}$ and $\mathrm{CRF}$ trees) in new stems; $\mathrm{N}$ accumulation (CRF and UF trees) and C export 

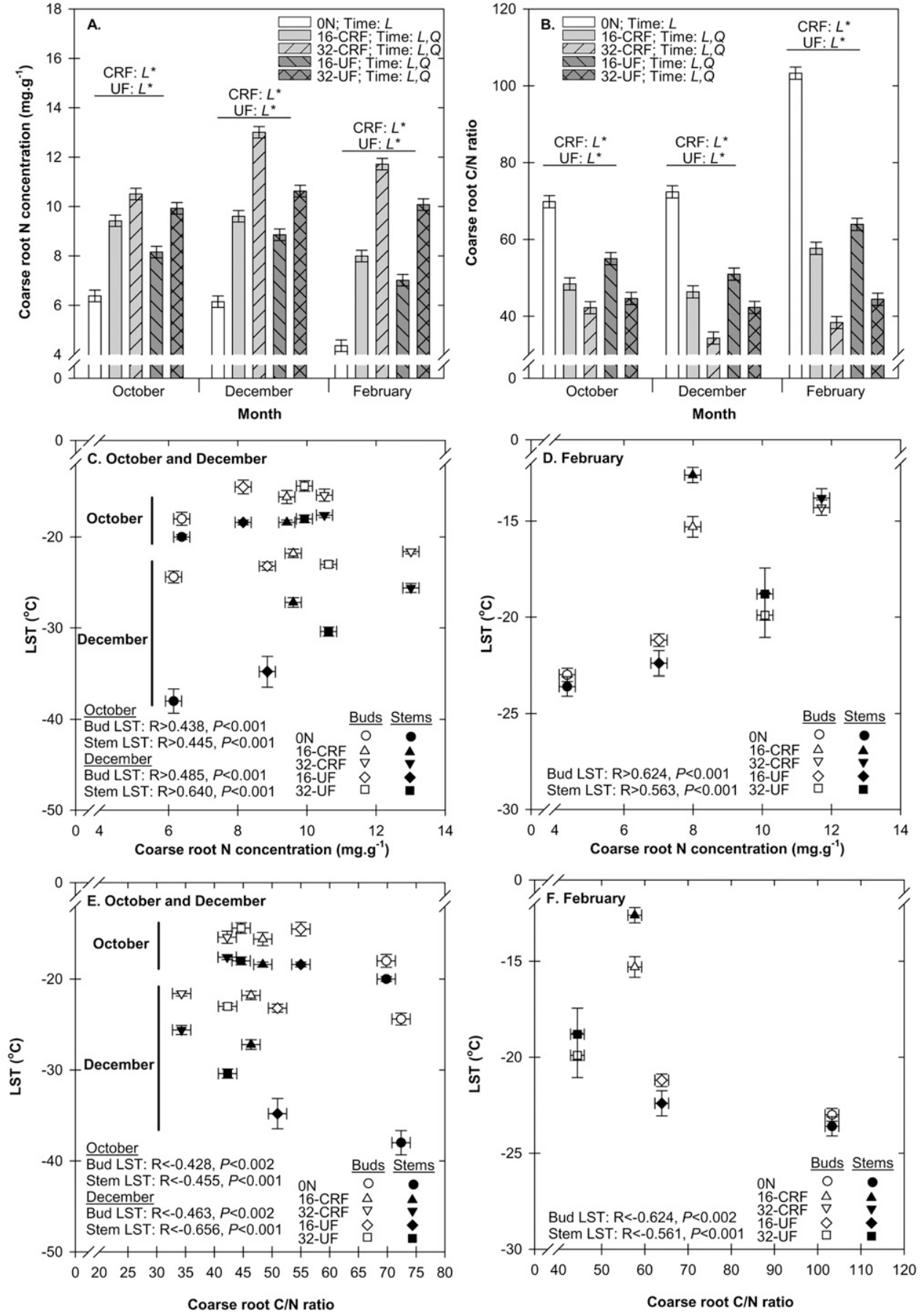

Fig. 4. Nitrogen $(\mathrm{N})$ concentration and carbon to $\mathrm{N}(\mathrm{C} / \mathrm{N})$ ratio in coarse roots of green ash trees after grown with different rates of $\mathrm{N}$ from two types of fertilizers in 2006. Measurements were taken on 24 Oct. 2006, 11 Dec. 2006 , and 5 Feb. 2007. $0 \mathrm{~N}=$ trees received no $\mathrm{N} . \mathrm{CRF}=$ trees fertilized with $16 \mathrm{~g} \mathrm{~N}(16-\mathrm{CRF})$ or $32 \mathrm{~g} \mathrm{~N}(32-\mathrm{CRF})$ from a controlled-release fertilizer. $\mathrm{UF}=$ trees fertilized with $16 \mathrm{~g} \mathrm{~N}(16-\mathrm{UF})$ or $32 \mathrm{~g} \mathrm{~N}(32-\mathrm{UF})$ from urea formaldehyde. Values are means and error bars are SE. (A-B) Influence of $\mathrm{N}$ treatment $(\mathrm{N}$ treatment) on $\mathrm{N}$ concentration and $\mathrm{C} / \mathrm{N}$ ratios. Significant $($ contrast $P<0.05)$ linear $(L)$ responses to $\mathrm{N}$ rate within a fertilizer type and date denoted above columns. Significant $(P<0.05)$ differences between fertilizer types in response to $\mathrm{N}$ rate within a date denoted by asterisks $\left({ }^{*}\right)$ adjacent to contrast letters above columns. Nonsignificant (NS) and significant (contrast $P>0.05) L$ and quadratic $(Q)$ responses over time within an $\mathrm{N}$ treatment denoted in captions. (C-F) Graphical representation of relationships between $\mathrm{N}$ concentrations and $\mathrm{C} / \mathrm{N}$ ratios and the lowest surviving temperature (LST) of buds and stems, including $P$ values for Spearman rank correlations $(R)$ within tissue type; $1 \mathrm{~g}=0.0353 \mathrm{oz} ; 1 \mathrm{mg} \cdot \mathrm{g}^{-1}=1000 \mathrm{ppm} ;\left(1.8 \times{ }^{\circ} \mathrm{C}\right)+32={ }^{\circ} \mathrm{F}$.

(CRF trees) from old stems; $\mathrm{N}$ and $\mathrm{C}$ accumulation in fine roots (CRF trees); and $\mathrm{N}$ accumulation in coarse roots (CRF and UF trees) (Figs. 2A-B, 3A-B, 4A-B, and $5 \mathrm{~A}-\mathrm{B})$.
The cold tolerance of buds and stems decreased between Dec. 2006 and Feb. 2007 (Fig. 1A-B) and was 

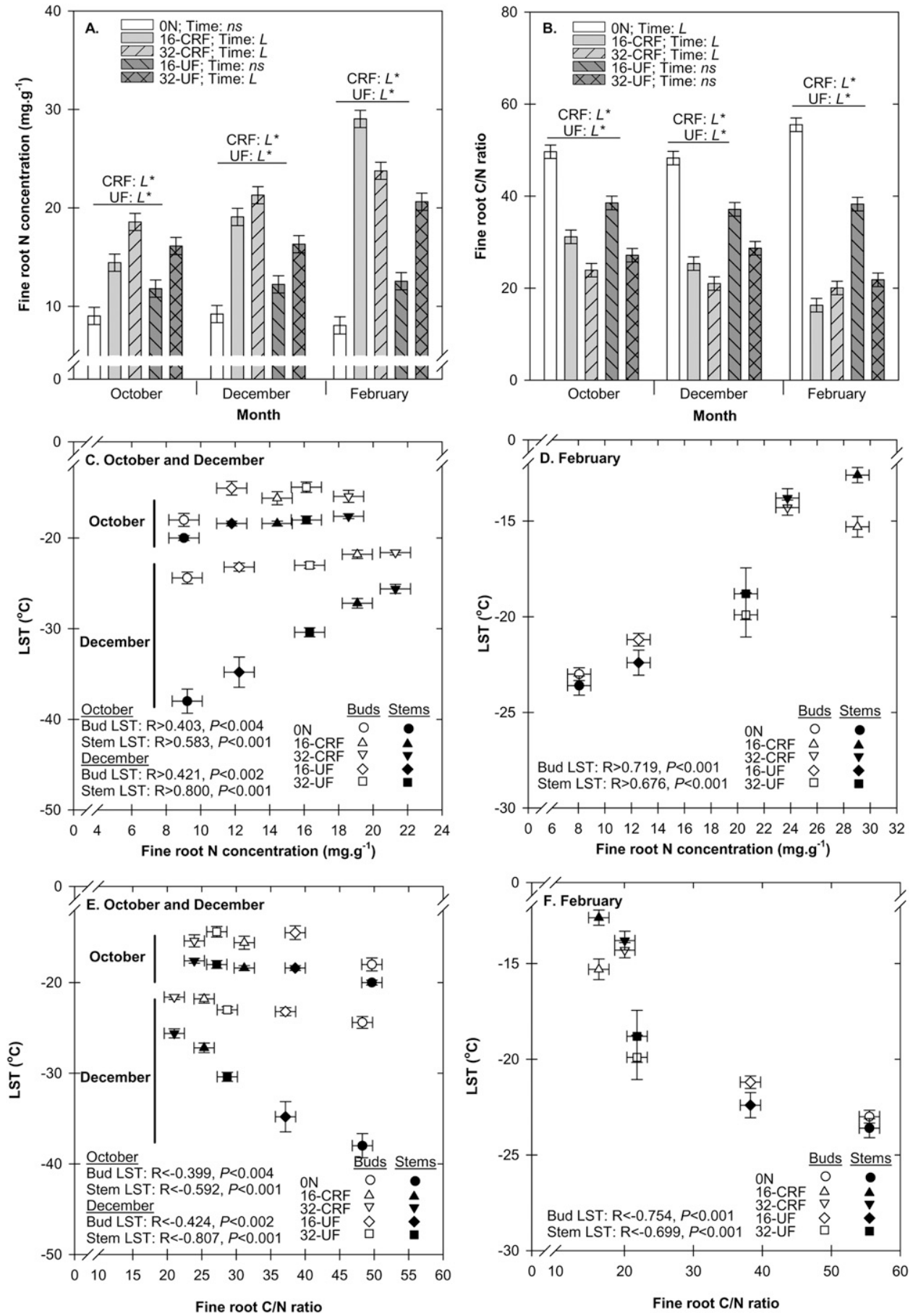

Fig. 5. Nitrogen $(N)$ concentration and carbon to $N(C / N)$ ratio in fine roots of green ash trees grown with different rates of $N$ from two types of fertilizers in 2006. Measurements were taken on 24 Oct. 2006, 11 Dec. 2006, and 5 Feb. 2007. 0N = trees received no $\mathrm{N}$. CRF = trees fertilized with $16 \mathrm{~g} \mathrm{~N}(16-\mathrm{CRF})$ or $32 \mathrm{~g} \mathrm{~N}(32-\mathrm{CRF})$ from a controlled-release fertilizer. $\mathrm{UF}=$ trees fertilized with $16 \mathrm{~g} \mathrm{~N}$ (16-UF) or $32 \mathrm{~g} \mathrm{~N}(32$-UF) from urea formaldehyde. Values are means and error bars are SE $(\mathrm{n}=10)$. (A-B) Influence of $\mathrm{N}$ treatment $(\mathrm{N}$ treatment) on $\mathrm{N}$ and $\mathrm{C} / \mathrm{N}$ ratios. Significant (contrast $\boldsymbol{P}<0.05$ ) linear $(L)$ responses to $\mathrm{N}$ rate within a fertilizer type and date denoted above columns. Significant $(P<0.05)$ differences between fertilizer types in response to $\mathrm{N}$ rate within a date denoted by asterisks $\left({ }^{*}\right)$ adjacent to contrast letters above columns. Nonsignificant (NS) and significant (contrast $P>0.05) L$ and quadratic $(Q)$ responses over time within an $\mathrm{N}$ treatment denoted in captions. (C-F) Graphical representation of relationships between $\mathrm{N}$ concentrations and $\mathrm{C} / \mathrm{N}$ ratios and the lowest surviving temperature (LST) of buds and stems, including $P$ values for Spearman rank correlations $(R)$ within tissue type; $1 \mathrm{~g}=0.0353 \mathrm{oz} ; 1 \mathrm{mg} \cdot \mathrm{g}^{-1}=1000 \mathrm{ppm} ;\left(1.8 \times{ }^{\circ} \mathrm{C}\right)+32={ }^{\circ} \mathrm{F}$.

related to $\mathrm{N}$ export $(0 \mathrm{~N}$ and $\mathrm{UF}$ trees) and $\mathrm{C}$ accumulation $(0 \mathrm{~N}$ and CRF trees) in new stems, $\mathrm{N}$ export and
$C$ accumulation in old stems $(0 \mathrm{~N}$, $\mathrm{CRF}$, and UF trees), and $\mathrm{N}$ loss $(0 \mathrm{~N}$ trees) and accumulation (CRF and
UF trees) in fine roots and $\mathrm{N}$ loss $(0 \mathrm{~N}, \mathrm{CRF}$, and UF trees) and C accumulation (CRF trees) in coarse 
roots (Figs. 2A-B, 3A-B, 4A-B, and $5 \mathrm{~A}-\mathrm{B})$.

\section{Discussion}

Nitrogen Rate. Green ash trees grown with low $\mathrm{N}$ availability in the growing substrate became more coldtolerant earlier in the winter, developed a higher level of cold tolerance, and retained a higher level of cold tolerance for longer than trees grown with a higher $\mathrm{N}$ availability (Fig. IA$\mathrm{B}$ ). Additionally, increasing $\mathrm{N}$ rate decreased midwinter cold tolerance of stems of UF and CRF trees and late winter cold tolerance of stems of UF trees. A review by Pellett and Carter (1981) on the relationship between nutrients and cold-hardiness concluded that plants fertilized at levels that promote optimum growth will generally cold-acclimate at a similar rate and to the same degree as plants grown under a lower fertility regime and in some instances their level of cold-hardiness development may exceed that of plants grown under severe nutrient deficiencies. Additionally, supraoptimum fertility levels can retard cold acclimation. Our results with green ash trees indicate stems and buds on trees that were grown with little $\mathrm{N}$ in 2006 were more cold-tolerant in Oct. 2006 and Feb. 2007 than trees given $\mathrm{N}$ at a rate similar to the industry standard $(32 \mathrm{~g}$ $\mathrm{N})$, and differences in LSTs between trees grown with 16 and $32 \mathrm{~g} \mathrm{~N}$ were greatest in Dec. 2006 and Feb. 2007. These results suggest that although the $32-\mathrm{g} \mathrm{N}$ rate may produce larger trees, these trees were potentially more prone to winter cold injury than trees grown at lower $\mathrm{N}$ rates. Kelly (1972) reported a decline in survival of 'Laland' firethorn (Pyracantha coccinea) resulting from increased $\mathrm{N}$ application rates, and Wright et al. (1978) found similar decreases in the overwinter survival of azalea ( $R$ hododendon spp.) cultivars grown with increasing rates of CRF (Osmocote). Others have reported an acceleration of cold-hardiness development with increased $\mathrm{N}$ fertility (Taulavuori et al., 2001).

Fertilizer type. Green ash trees fertilized with UF developed a higher level of midwinter cold tolerance and retained a higher level of cold tolerance for longer than trees grown with CRF (Fig. 1A-B). These results indicate CRF trees may not become as cold-tolerant as UF trees and, as bud break results indicated, CRF trees potentially become less dormant or less cold-tolerant more rapidly in the spring than UF trees. Some researchers have demonstrated that treatment differences in foliar cation nutrition, tree physiology, growth, and mortality better reflect absolute $\mathrm{N}$ treatment rates than they do the form of $\mathrm{N}$ applied (Birchler et al., 2001; Raker and Dirr, 1979; Schaberg et al., 2002). Although certain plant species have preferences for different forms of $\mathrm{N}$, the type of fertilizer used to deliver $\mathrm{N}$ may be more important for many plant species than the form of $\mathrm{N}$. This may have to do with differences in timing of nutrient release and other things. Although the same amount of $\mathrm{N}$ was applied to trees in the form of UF or CRF, differences in temporal availability of $\mathrm{N}$ and $\mathrm{N}$ form between the two fertilizer types resulted in differences in $\mathrm{N}$ import to new above ground growth. For example, on average, for every gram of $\mathrm{N}$ applied, 2006 stems on UF trees accumulated $3.76 \mathrm{~g}$ biomass and $43.2 \mathrm{mg} \mathrm{N}$ and 2006 stems of CRF trees accumulated $6.45 \mathrm{~g}$ biomass and $74.7 \mathrm{mg} \mathrm{N}$. These results suggest UF and CRF differentially influenced $\mathrm{N}$ import or demand by new above ground growth. Fertilizer type has previously been shown to influence allocation of $\mathrm{N}$ and $\mathrm{C}$ by green ash trees (Scagel et al., 2010).

Fertilizer type altered the timing of $\mathrm{N}$ and $\mathrm{C}$ translocation and metabolism in stems and roots of green ash trees during the fall and winter and how trees balanced $\mathrm{N}$ and $\mathrm{C}$ (Figs. $2 \mathrm{~A}-\mathrm{B}, 3 \mathrm{~A}-\mathrm{B}, 4 \mathrm{~A}-\mathrm{B}$, and $5 \mathrm{~A}-\mathrm{B})$. Plant cold tolerance has been related to high $\mathrm{N}$ concentrations and low $\mathrm{C} / \mathrm{N}$ ratios in stems (Thomas and Ahlers, 1999; Thomas and Blank, 1996) suggesting these variables reflect some of the physiological changes in carbohydrates and $\mathrm{N}$-containing compounds that occur during cold acclimation and the relationship of these compounds to deacclimation and resource demands in the spring. Our results suggest the influence of $\mathrm{N}$ rate on cold tolerance of green ash trees involves $\mathrm{C}$ and $\mathrm{N}$ metabolism of the older stems and coarse roots during the early stages of coldhardiness development (October) with an emphasis on $\mathrm{C}$ activity, and the level of cold tolerance in midwinter
(December) and late winter (February) involves $\mathrm{C}$ and $\mathrm{N}$ metabolism in new and old stems and $\mathrm{C}$ metabolism in coarse roots. Additionally, the influence of fertilizer type on composition was not related to early stages of cold-hardiness development and appears to be related to differences in $\mathrm{C}$ activity in stems during the midwinter and late winter and $\mathrm{N}$ and $\mathrm{C}$ activity in fine roots during the midwinter. Although there may be a direct role of $\mathrm{N}$ and $\mathrm{C}$ composition and metabolism of stems on cold tolerance of stem and bud tissues (Thomas and Ahlers, 1999; Thomas and Blank, 1996), root composition can only play an indirect role in cold tolerance of above ground tissues through the effects of root composition on resource storage, translocation, and allocation (Atkinson et al., 2007; Livingston et al., 2006).

NITROGEN AND CARBON DYNAMICS. The cold tolerance of stems and buds on green ash trees increased between Oct. and Dec. 2006 and decreased from Dec. 2006 to Feb. 2007 (Fig. lA-B). Temperate woody perennial plants have the ability to survive low winter temperature as a result of their ability to progressively increase their tolerance to cold temperature during the fall and achieve maximal cold-hardiness by midwinter (Marian et al., 2003). Changes in $\mathrm{C}$ and $\mathrm{N}$ metabolism occur in tissues of green ash between Oct. 2006 and Feb. 2007 , in theory encompassing the different stages of cold acclimation. Increased cold tolerance between Oct. and Dec. 2006 was related to changes in direction of $\mathrm{N}$ and $\mathrm{C}$ shifts in stems and roots, and decreased cold tolerance between Dec. 2006 to Feb. 2007 was related to changes in both the magnitude and direction of $\mathrm{N}$ and $\mathrm{C}$ shifts in stems and roots (Figs. 2A-B, 3A-B, 4A-B, and $5 \mathrm{~A}-\mathrm{B})$.

Cold acclimation occurs in at least three stages (Fuchigami et al., 1971, 1982). The first stage is generally induced by shortening day length in the fall, the second stage by low temperatures in the fall and early winter, and a third stage of maximal coldhardiness is reached after prolonged exposure to low temperature. Physiological changes that occur during cold acclimation in plants include increased concentrations of sugars, desaturated lipids, organic acids, proline, 
and soluble proteins (Hughes and Dunn, 1990). Certain proteins such as dehydrins have been associated with freeze tolerance in several woody perennial plants, including blueberry [Vaccinium corymbosum (Panta et al., 2001)], rhododendron [Rhododendron spp. (Marian et al., 2003)], and peach [Prunus persica (Wisniewski et al., 1999)]. Our results indicate trees exporting $\mathrm{N}$ and importing $\mathrm{C}$ into new stems between Oct. and Dec. 2006 (0N trees) developed a higher level of cold tolerance than trees importing $\mathrm{N}$ into new stems (UF trees); trees with relatively stable $\mathrm{N}$ and $\mathrm{C}$ concentrations in old stems between Oct. and Dec. 2006 (0N trees) developed a higher level of cold tolerance than trees importing $\mathrm{C}$ and $\mathrm{N}$ into old stems (CRF trees); and trees with no net change in $\mathrm{C}$ and $\mathrm{N}$ in roots $(0 \mathrm{~N}$ trees $)$ developed a higher level of cold tolerance than trees accumulating $\mathrm{N}$ or $\mathrm{C}$ in roots between Oct. and Dec. 2006 (CRF and UF trees).

Dehardening or deacclimation in the late winter and early spring usually occurs in response to warm temperatures and results in the metabolism and translocation of storage reserves (Kalberer et al., 2006). The terms "rehardening" or "reacclimation" have been used to describe the restoration of at least a portion of the lost hardiness after reversible deacclimation and subsequent exposure to low temperatures. The existence of high deacclimation resistance and reacclimation capacity in late winter and early spring is often important in preventing damage from low temperatures that follow periods of unseasonable, transient warm spells (Kozlowski and Pallardy 2002). Many changes in metabolism accompany cold acclimation and deacclimation such as increasing levels of raffinose family oligosaccharides and other soluble sugars during cold acclimation in several woody species (Cox and Stushnoff, 2001). Our results indicate trees exporting $\mathrm{N}$ in conjunction with a high rate of $\mathrm{C}$ accumulation in stems between Dec. 2006 and Feb. 2007 (0N trees) maintained a higher level of cold tolerance than trees with smaller changes in $\mathrm{N}$ and $\mathrm{C}$ in stems (UF and CRF trees); trees exporting $\mathrm{N}$ while maintaining relatively stable $\mathrm{C}$ concentrations in new stems (UF trees) between Dec. 2006 and Feb. 2007 maintained a higher level of cold tolerance than trees importing $\mathrm{C}$ into new stems (CRF trees); trees with no net change of $\mathrm{C}$ in coarse roots $(0 \mathrm{~N}$ and UF) trees maintained a higher level of cold tolerance than trees accumulating $\mathrm{C}$ in coarse roots between Dec. 2006 and Feb. 2007 (CRF trees); and trees exporting $\mathrm{N}$ from fine roots $(0 \mathrm{~N}$ trees) between Dec. 2006 and Feb. 2007 maintained a higher level of cold tolerance than trees importing $\mathrm{N}$ to fine roots (CRF and UF trees).

RELATIONSHIPS BETWEeN COLD TOLERANCE AND COMPOSITION. Relationships between $\mathrm{N}$ and $\mathrm{C}$ composition and cold tolerance occurred at several harvest dates and varied between tissues (Figs. 2C-F, 3C-F, 4C$\mathrm{F}$, and $5 \mathrm{C}-\mathrm{F})$. Differences in the relationship between cold tolerance and composition of different tissues over time may be related to differences in the timing of mobilization, import, and export of $\mathrm{C}$ and $\mathrm{N}$ between trees grown with the different rates and types of fertilizer (Scagel et al., 2010). Our results indicate early stages of cold tolerance development in green ash trees are related to the export of $\mathrm{N}$ and import of $\mathrm{C}$ into stems, whereas retention of midwinter hardiness involves the maintenance of higher $\mathrm{C} / \mathrm{N}$ ratios in tissues. In general, higher $\mathrm{C} / \mathrm{N}$ ratios in all tissues were related to higher cold tolerance and higher $\mathrm{N}$ concentrations were related to lower cold tolerance. This suggests the balance between $\mathrm{C}$ and $\mathrm{N}$ may be as important as $\mathrm{N}$ in relationship to cold tolerance, particularly in late winter and early spring when there is a high potential for bud and stem damage to occur. Guak and Fuchigami (2002) determined that foliar applications of urea in the fall increase stem $\mathrm{N}$ concentrations, decrease the concentrations of total nonstructural carbohydrates in stems, and improved new growth of 'Gala' apple (Malus $\times$ domestica) the next spring. This increase in stem $\mathrm{N}$ and corresponding decreased in stem carbohydrates may have potentially decreased the $\mathrm{C} / \mathrm{N}$ ratios in stem tissues. fall applications of urea can increase cold tolerance of plants (Zilkah et al., 1996). The influence of fall urea applications on cold tolerance may be a result of a change in balance between $\mathrm{N}$ and $\mathrm{C}$ in stem tissues. There is also some genetic evidence linking the upregulation of certain genes by low temperature and the balance between $\mathrm{C}$ and $\mathrm{N}$ in plants (Watanabe et al., 2008).

In Dec. 2006 and Feb. 2007, there were significant relationships between cold tolerance and $\mathrm{N}$ concentration and $\mathrm{C} / \mathrm{N}$ ratios for all tissues. In general, changes in $\mathrm{N}$ concentrations and $\mathrm{C} / \mathrm{N}$ ratios in CRF trees were related to larger changes in bud and stem cold tolerance than similar changes in $\mathrm{N}$ and $\mathrm{C} / \mathrm{N}$ ratios in $\mathrm{UF}$ trees. The 16-UF trees were more cold-tolerant in Feb. 2007 and resumed visible bud growth $7 \mathrm{~d}$ later than 32-UF trees. These results suggest trees grown with a higher $\mathrm{N}$ rate become less dormant or less coldhardy more rapidly in the spring than trees grown at lower $\mathrm{N}$ rates. As stated at the beginning of this article, there are conflicting reports regarding the effect of fertilizer application rate on cold tolerance of perennial plants. In contrast to our results, several researchers have reported positive relationships between plant $\mathrm{N}$ and tolerance to freezing occurred after $\mathrm{N}$ fertilizer application and others have shown decreased or no change in hardiness after $\mathrm{N}$ fertilization (Alden and Hermann, 1971; Daten and Johnsen, 2004; Teets and Hummel, 1985).

The exact relationship of $\mathrm{N}$ with hardiness may strongly depend on plant and environmental factors, which could explain differences between results. For example, high $\mathrm{N}$ availability can increase growth of container-grown plants and result in a higher plant demand for water. Drought can decrease $C$ gain in plants and this decrease has been related to lower cold tolerance (Dickson, 1989; Thomas and Ahlers, 1999). Also, the interactions between cold damage and fertilizer form, timing of $\mathrm{N}$ availability, and the effect of $\mathrm{N}$ availability on uptake of other nutrients are not well understood. For example, Scagel et al. (2008a, 2008b) demonstrated $\mathrm{N}$ availability and fall application of urea can alter uptake and demand for other nutrients by evergreen and deciduous azalea and rhododendron cultivars. Others have reported there is a stronger relationship between cold tolerance and plant $\mathrm{K}$ status than plant N status (Jalkanen et al., 1998; Lindstrom et al., 2002). Differences in cold tolerance of green ash grown 
with different fertilizer types may be related to differences in the timing of nutrient availability and differences in uptake of other nutrients between fertilizers.

Cold damage has been associated with bud and shoot damage of ash trees (Pukacki and Przybył, 2005). Previous research has shown providing $\mathrm{N}$ as ammonium nitrate in $\mathrm{CRF}$ increases bud failure and shoot dieback symptoms of green ash trees compared with trees grown with UF (Scagel et al., 2010). The results from the present study suggest these differences in bud failure may be related to greater cold tolerance of green ash trees grown with $\mathrm{N}$ from UF compared with trees grown with CRF. Results from both studies indicate higher bud failure and reduced cold tolerance are associated with higher $\mathrm{N}$ concentrations, lower $\mathrm{C} / \mathrm{N}$ ratios, and differences in $\mathrm{N}$ partitioning between trees fertilized with $\mathrm{N}$ as CRF and UF. Our results indicate green ash trees with a similar $\mathrm{N}$ status can tolerate different levels of cold depending on the type of fertilizer used during production.

\section{Literature cited}

Alden, J. and R.K. Hermann. 1971. Aspects of the cold-hardiness mechanism in plants. Bot. Rev. 37:37-142.

Aniśko, T., O.M. Lindstrom, and G. Hoogenboom. 1994. Development of a cold hardiness model for deciduous woody plants. Physiol. Plant. 91:375382 .

Atkinson, L.J., M.A. Hellicar, A.H. Fitter, and O.K. Atkin. 2007. Impact of temperature on the relationship between respiration and nitrogen concentration in roots: An analysis of scaling relationships, Q10 values, and thermal acclimation ratios. New Phytol. 173:110-120.

Bi, G., C.F. Scagel, L. Cheng, and L.H. Fuchigami. 2005. Effects of copper, zinc, and urea on defoliation and nitrogen reserves in nursery plants of almond. J. Hort. Sci. Biotechnol. 80:746-750.

Bigras, F.J., A. Gonzalez, A.L. D'Aoust, and C. Hébert. 1996. Frost hardiness, bud phenology, and growth of containerized Picea mariana seedlings grown at three nitrogen levels and three temperature regimes. New For. 12:243-259.

Birchler, T.M., R.W. Rose, and D.L. Haase. 2001. Fall fertilization with N and K: Effects on douglas-fir seedling quality and performance. West. J. Appl. For. 16:71-79.

Buamscha, M.G., J.E. Altland, D.M. Sullivan, D.A. Horneck, and J.P.G. McQueen. 2008. Nitrogen availability in fresh and aged douglas-fir bark. HortTechnology 18:619-623.

Calmé, S. and H.A. Margolis. 1993. Influence of cultural practices on the relationship between frost tolerance and water content of containerized black spruce, white spruce, and jack pine seedlings. Can. J. For. Res. 23:503-511.

Cappiello, P.E. and L.E. Littlefield. 1994. Woody landscape plant cold-hardiness ratings. Maine Agr. Forest Expt. Sta. Tech. Bul. 156.

Colombo, S.J., C.G. Lerum, and D.P. Webb. 2003. Daylength, temperature, and fertilization effects on desiccation resistance, cold hardiness, and root growth potential of Picea mariana seedlings. Ann. For. Sci. 60:307-317.

Cox, S.E. and C. Stushnoff. 2001. Temperature-related shifts in soluble carbohydrate content during dormancy and cold acclimation in Populus tremuloides. Can. J. For. Res. 31:730-737.

Daten, L.S. and Ø. Johnsen. 2004. $\mathrm{CO}_{2}$ enrichment, nitrogen fertilization and development of freezing tolerance in norway spruce. Trees Structure Function 18: 10-18

Dickson, R.E. 1989. Carbon and nitrogen allocation in trees. Ann. Sci. For. 46: 631s-647s.

Fløistad, I.S. 2002. Effects of excessive nutrient supply and short day treatment on autumn frost hardiness and time of bud break in Picea abies seedlings. Scand. J. For. Res. 17:295-303.

Fløistad, I.S. and K. Kohmann. 2004. Influence of nutrient supply on spring frost hardiness and time of bud break in norway spruce [Picea abies (L.) Karst.] seedlings. New For. 27:1-11.

Fuchigami, L.H., C.J. Weiser, and D.R. Evert. 1971. Induction of cold acclimation in Cornus stolonifera Michx. Plant Physiol. 47:98-103.

Fuchigami, L.H., C.J. Weiser, K. Kobayashi, R. Timmis, and L.V. Gusta. 1982. A degree growth stage $\left({ }^{\circ} \mathrm{GS}\right)$ model and cold acclimation in temperate wood plants, p. 93-116. In: P.H. Li. and A. Sakai (eds.). Plant cold hardiness and freezing studies. Academic Press, New York, NY.

Guak, S. and L.H. Fuchigami. 2002. Foliar applications of urea or ABA affect growth cessation, leaf senescence and abscission, cold acclimation and levels of reserve nitrogen and carbohydrates in nitrogen-treated apple nursery plants. J. Hort. Sci. Biotechnol. 77:137-142.

Hellergren, J. 1981. Frost hardiness development in Pinus sylvestris seedlings in response to fertilization. Physiol. Plant. 52:297-301.

Hughes, M.A. and M.A. Dunn. 1990. The effect of temperature on plant growth and development. Biotechnol. Genet. Eng. Rev. 8:161-188.

Hummel, R.L., P.D. Ascher, and H.M. Pellett. 1982. Inheritance of the phyotoperiodically induced cold acclimation response in Cornus sericea L., red-osier dogwood. Theor. Appl. Genet. 62:385394.

Jalkanen, R.E., D.B. Redfern, and L.J. Sheppard. 1998. Nutrient deficits increase frost hardiness in sitka spruce (Picea sitchensis) needles. For. Ecol. Mgt. 107:191201.

Kalberer, S.R., R. Arora, N. LeyvaEstrada, and S.L. Krebs. 2007. Cold hardiness of floral buds of deciduous azaleas: Dehardening, rehardening, and endodormancy in late winter. J. Amer. Soc. Hort. Sci. 132:73-79.

Kalberer, S.R., M. Wisniewski, and R. Arora. 2006. Deacclimation and reacclimation of cold-hardy plants: Current understanding and emerging concepts. Plant Sci. 171:3-16.

Kelly, J.D. 1972. Nitrogen and potassium rate effects on growth, leaf nitrogen, and winter hardiness of Pyracantha coccinea 'Lalandi' and Ilex crenata 'Rotundifolia'. J. Amer. Soc. Hort. Sci. 97:446-448.

Kozlowski, T.T. and S.G. Pallardy. 2002. Acclimation and adaptive responses of woody plants to environmental stresses. Bot. Rev. 68:270-334.

Lindstrom, O.M., R.B. Beverly, and H.A. Mills. 2002. Neither bloom period nor postbloom nitrogen application reduces cold hardiness in crapemyrtle. Commun. Soil Sci. Plant Anal. 33:3837-3844.

Livingston, D.P., R. Premakumar, and S.P. Tallury. 2006. Carbohydrate partitioning between upper and lower regions of the crown in oat and rye during cold acclimation and freezing. Cryobiology 52:200-208.

Marian, C.O., S.L. Krebs, and R. Arora. 2003. Dehydrin variability among rhododendron species: A $25-\mathrm{kDa}$ dehydrin is conserved and associated with cold acclimation across diverse species. New Phytol. 161:773-780.

Munshaw, G.C., E.H. Ervin, C. Shang, S.D. Askew, X. Zhang, and R.W. Lemus. 2006. Influence of late-season iron, nitrogen, and 
seaweed extract on fall color retention and cold tolerance of four bermudagrass cultivars. Crop Sci. 46:273-283.

Panta, G.R., M.W. Rieger, and L.J. Rowland. 2001. Effect of cold and drought stress on blueberry dehydrin accumulation. J. Hort. Sci. Biotechnol. 76:549-556.

Pellett, H., M. Gearhart, and M. Dirr. 1981. Cold hardiness capability of woody ornamental plant taxa. J. Amer. Soc. Hort. Sci. 106:239-243.

Pellett, H.M. and J.V. Carter. 1981. Effect of nutritional factors on cold hardiness of plants. Hort. Rev. (Amer. Soc. Hort. Sci.) 3:144-171.

Pukacki, P.M. and K. Przybył. 2005. Frost injury as a possible inciting factor in bud and shoot necroses of Fraxinus excelsior L. J. Phytopathol. 153:512-516.

Raker, R.J. and M.A. Dirr. 1979. Effect of nitrogen form and rate on appearance and cold acclimation of three container-grown woody ornamentals. Scientia Hort. 10: $231-236$

Rikala, R. and T. Repo. 1997. The effect of late summer fertilization on the frost hardening of second-year scots pine seedling. New For. 14:33-44.

Scagel, C.F., G. Bi, R.P. Regan, and L.H. Fuchigami. 2007. Seasonal variation in growth, nitrogen uptake and allocation by container-grown Rhododendron cultivars. HortScience 45:1440-1449.

Scagel, C.F., G. Bi, L.H. Fuchigami, and R.P. Regan. 2008a. Rate of nitrogen application during the growing season and spraying plants with urea in the autumn alters uptake of other nutrients by deciduous and evergreen containergrown Rhododendron cultivars. HortScience 43:1569-1579.

Scagel, C.F., G. Bi, R.P. Regan, and L.H. Fuchigami. 2008b. Nitrogen availability alters mineral nutrient uptake and demand in container-grown deciduous and evergreen Rhododendron. J. Environ. Hort. 26:177-187.

Scagel, C.F., R.P. Regan, and G. Bi. 2010. Bud necrosis of green ash nursery trees is influenced by nitrogen availability and fertilizer type. HortTechnology (in press).

Schaberg, P.G., D.H. DeHayes, G.J. Hawley, P.F. Murakami, G.R. Strimbeck, and S.G. McNulty. 2002. Effects of chronic $\mathrm{N}$ fertilization on foliar membranes, cold tolerance, and carbon storage in montane red spruce. Can. J. For. Res. 32:1351-1359.

Smiley, E.T. and A.M. Shirazi. 2003. Fall fertilization and cold hardiness in landscape trees. J. Arboriculture 29:342-346.

Sterigios, B.G. and G.S. Howell, Jr. 1973. Evaluation of viability tests for coldstressed plants. J. Amer. Soc. Hort. Sci. 98:325-330.

Taulavuori, K., E. Taulavuori, A. Niinimaa, and K. Laine. 2001. Acceleration of frost hardening in Vaccinium vitis-idaea by nitrogen fertilization. Oecologia 127: $321-323$.

Teets, T.M. and R.L. Hummel. 1985. Nutritional effects on cold acclimation of Hibiscus syriacus. Proc. Florida State Hort. Soc. 98:90-92.
Teets, T.M., R.L. Hummel, and C.L. Guy. 1989. Cold-acclimation of Hibiscus rosa-sinensis L. and Hibiscus syriacus $\mathrm{L}$. in natural and controlled environments. Plant Cell Environ. 12:495-502.

Thomas, F.M. and U. Ahlers. 1999. Effects of excess nitrogen on frost hardiness and freezing injury of above-ground tissue in young oaks (Quercus petraea and Q. robur). New Phytol. 144:73-83.

Thomas, F.M. and R. Blank. 1996. The effect of excess nitrogen and of insect defoliation on the frost hardiness of bark tissue of adult oaks. Ann. Sci. For. 53:395406.

Watanabe, C.K., T. Hachiga, I. Terashima, and K. Noguchi. 2008. The lack of alternative oxidase at low temperature leads to a disruption of the balance in carbon and nitrogen metabolism, and to an upregulation of antioxidant defense systems in Arabidopsis thaliana leaves. Plant Cell Environ. 31:1190-1202.

Wisniewski, M., R. Webb, R. Balsamo, T.J. Close, X.M. Yu, and M. Griffith. 1999. Purification, immunolocalization, cryoprotective, and antifreeze activity of PCA60: A dehydrin from peach (Prunus persica). Physiol. Plant. 105:600-608.

Wright, R.D., M.F. George, and D.C. Milbocker. 1978. Effects of Osmocote rate on winter survival of two container grown azalea cultivars. Southern Nurserymen Assn. Res. J. 5:27-34.

Zilkah, S., Z. Wiesmann, I. Klein, and I. David. 1996. Foliar applied urea improves freezing protection to avocado and peach. Scientia Hort. 66:85-92. 